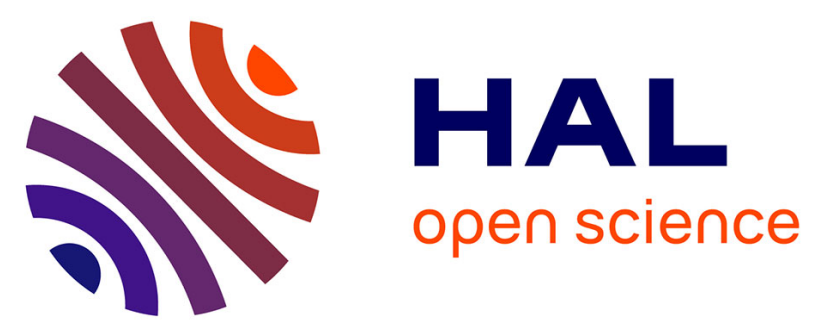

\title{
Complete removal of arsenic and zinc from a heavily contaminated acid mine drainage via an indigenous SRB consortium
}

\author{
Pierre Le Pape, Fabienne Battaglia-Brunet, Marc Parmentier, Catherine \\ Joulian, Cindy Gassaud, Lidia Fernandez-Rojo, Jean-Michel Guigner, Maya \\ Ikogou, Lucie Stetten, Luca Olivi, et al.
}

\section{To cite this version:}

Pierre Le Pape, Fabienne Battaglia-Brunet, Marc Parmentier, Catherine Joulian, Cindy Gassaud, et al.. Complete removal of arsenic and zinc from a heavily contaminated acid mine drainage via an indigenous SRB consortium. Journal of Hazardous Materials, 2017, 321 (5), pp. 764-772. 10.1016/j.jhazmat.2016.09.060 . hal-01383818

\section{HAL Id: hal-01383818 https://hal.sorbonne-universite.fr/hal-01383818}

Submitted on 19 Oct 2016

HAL is a multi-disciplinary open access archive for the deposit and dissemination of scientific research documents, whether they are published or not. The documents may come from teaching and research institutions in France or abroad, or from public or private research centers.
L'archive ouverte pluridisciplinaire HAL, est destinée au dépôt et à la diffusion de documents scientifiques de niveau recherche, publiés ou non, émanant des établissements d'enseignement et de recherche français ou étrangers, des laboratoires publics ou privés. 


\section{Complete removal of arsenic and zinc from a heavily contaminated}

\section{Acid Mine Drainage via an indigenous SRB consortium}

Pierre Le Pape ${ }^{1}$, Fabienne Battaglia-Brunet ${ }^{2}$, Marc Parmentier ${ }^{2}$, Catherine Joulian ${ }^{2}$, Cindy Gassaud $^{2}$, Lidia Fernandez-Rojo ${ }^{3}$, Jean-Michel Guigner ${ }^{1}$, Maya Ikogou ${ }^{1}$, Lucie Stetten ${ }^{1}$, Luca Olivi $^{4}$, Corinne Casiot ${ }^{3}$, and Guillaume Morin ${ }^{1}$

1 Sorbonne Universités - Institut de Minéralogie, de Physique des Matériaux et de Cosmochimie (IMPMC), UMR IRD 206, UPMC Université Paris VI, 4 place Jussieu, 75252 Paris cedex 05, France.

${ }^{2}$ French Geological survey (BRGM), 3 av. Claude Guillemin, 45060, BP 36009, Orléans Cedex 2, France.

3 HydroSciences Montpellier, UMR 5569 CNRS-IRD-UM, CC57, 163 rue Auguste Broussonet, 34090 Montpellier, France.

${ }^{4}$ Sincrotrone Trieste ELETTRA, I-34012 Trieste, Italy.

Corresponding Author : Pierre Le Pape

pierrelp.hm@gmail.com

Submitted to Journal of Hazardous Material 
Graphical abstract

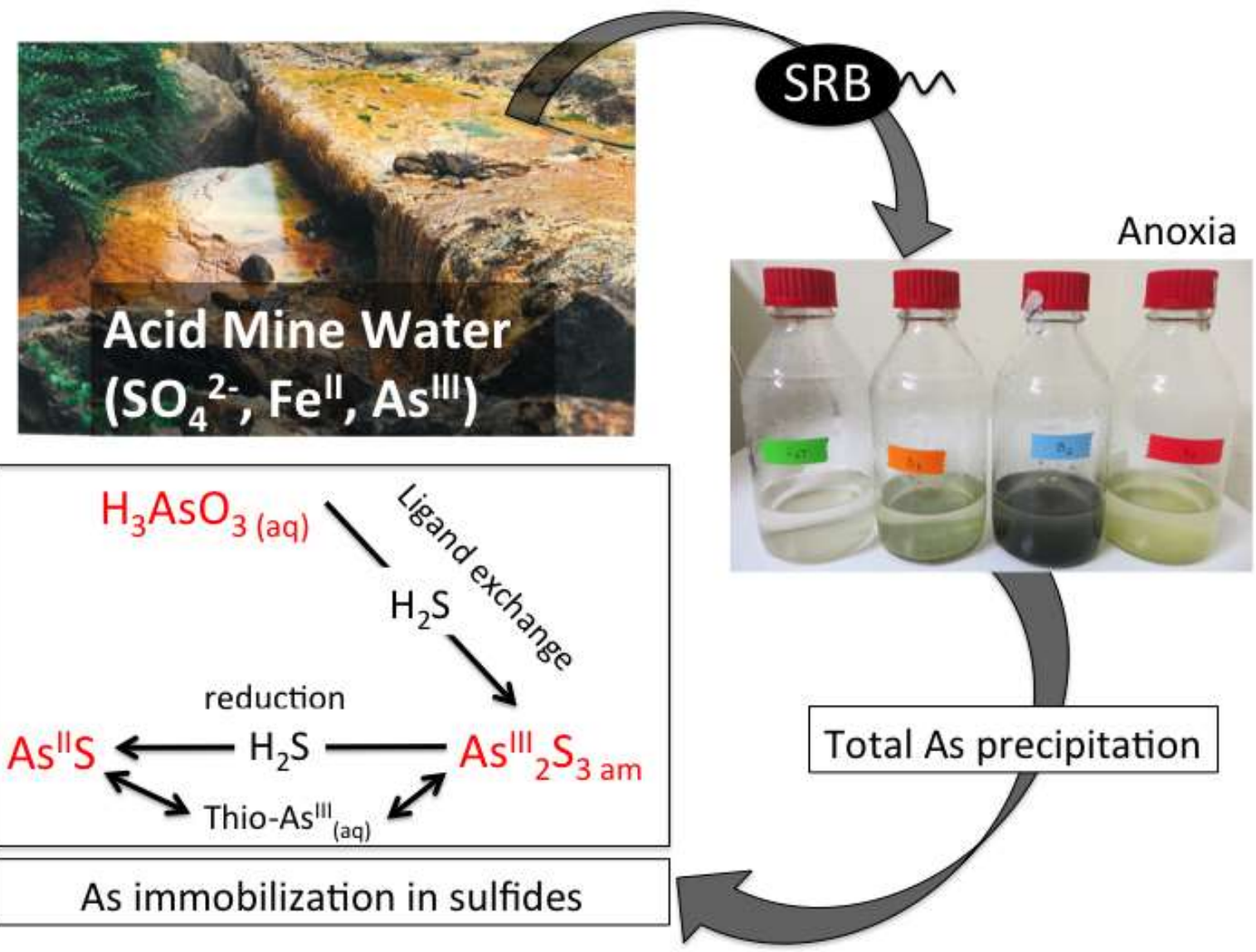

\section{Highlights}

- SRB activity is evidenced at acidic $\mathrm{pH}$ in acid mine drainage water

- Total arsenic and zinc removal from solution is observed

- As, $\mathrm{Zn}$ and Fe are observed to precipitate as biogenic sulfides

- Amorphous orpiment $\left(\mathrm{As}_{2}{ }_{2} \mathrm{~S}_{3}\right)$ and realgar $\left(\mathrm{As}{ }^{\mathrm{II}} \mathrm{S}\right)$ are observed as main As-bearing sulfides

- A mechanism is proposed for the reduction of $\mathrm{As}_{2} \mathrm{~S}_{3}$ to $\mathrm{AsS}$ by biogenic $\mathrm{H}_{2} \mathrm{~S}$ under acidic conditions 


\begin{abstract}
Acid mine drainages (AMD) are major sources of pollution to the environment. Passive bioremediation technologies involving sulfate-reducing bacteria (SRB) are promising for treating arsenic contaminated waters. However, mechanisms of biogenic As-sulfide formation need to be better understood to decontaminate AMDs in acidic conditions. Here, we show that a highAs AMD effluent can be decontaminated by an indigenous SRB consortium. AMD water from the Carnoulès mine (Gard, France) was incubated with the consortium under anoxic conditions and $\mathrm{As}, \mathrm{Zn}$ and $\mathrm{Fe}$ concentrations, $\mathrm{pH}$ and microbial activity were monitored during 94 days. Precipitated solids were analyzed using electron microscopy (SEM/TEMEDXS), and Extended X-Ray Absorption Fine Structure (EXAFS) spectroscopy at the As Kedge. Total removal of arsenic and zinc from solution (1.06 and $0.23 \mathrm{mmol} / \mathrm{L}$, respectively) was observed in two of the triplicates. While $\mathrm{Zn}$ precipitated as $\mathrm{ZnS}$ nanoparticles, As precipitated as thiol-bound $\mathrm{As}{ }^{\mathrm{III}}(14-23 \%)$, amorphous orpiment (am-As $\left.{ }^{\mathrm{III}}{ }_{2} \mathrm{~S}_{3}\right)(33-73 \%)$, and realgar $\left(\mathrm{As}^{\mathrm{II}} \mathrm{S}\right)(0-34 \%)$, the latter phase exhibiting a particular nanowire morphology. We propose that the formation of the $\mathrm{As}^{\mathrm{II}} \mathrm{S}$ nanowires results from $\mathrm{As}^{\mathrm{III}}{ }_{2} \mathrm{~S}_{3}$ reduction by biogenic $\mathrm{H}_{2} \mathrm{~S}$, enhancing the efficiency of As removal. The present description of As immobilization may help to set the basis for bioremediation strategies using SRB.
\end{abstract}

Keywords: arsenic, bioremediation, sulfate-reducing bacteria, biogenic sulfides, acid mine drainage 


\section{Introduction}

Arsenic (As) is harmful for most of the living organisms when present at toxic concentrations in water, soils and sediments [1, 2]. In acid mine drainages (AMD), As concentrations in water can lead to environmental threats [3-5], unless remediation technologies are implemented. Passive (bio)remediation systems (PBS) that utilize the local conditions to selectively immobilize As represent cost-effective solutions to treat such contaminated waters [6]. However, a better knowledge of As biomineralization mechanisms is required to promote the highest As removal rate.

In As-rich AMD waters, As is usually immobilized by coprecipitation with iron hydroxysulfates [7-11]. This mechanism involves microbially mediated reactions that lead to incomplete removal of As $[9,11,12]$. In such cases, anaerobic bioprocesses based on sulfatereducing bacteria (SRB) may be considered as alternative solution, even for acidic AMD media. Indeed, although most of the studies that have addressed with SRB-mediated removal of As were performed at circumneutral $\mathrm{pH}$ [13-18], recent studies have shown that sulfatereducing metabolisms can occur in acidophilic conditions [19-22] and specific SRB strains were isolated [22-25]. Finally, As removal was successfully performed in acidic media using SRB consortia in biochemical reactors [26, 27].

Newman et al. [13] brought evidence for biogenic arsenic precipitation in the form of amorphous orpiment $\left(\mathrm{am}-\mathrm{As}_{2} \mathrm{~S}_{3}\right)$ in the presence of SRB. Recent studies have shown that the precipitation of arsenic as orpiment $\left(\mathrm{As}_{2} \mathrm{~S}_{3}\right)$ or realgar (AsS) can lead to massive As removal from solution $[14,16,17,26,27]$. Besides, such biogenic minerals possibly serve as precursors to the formation of rare sulfide minerals upon maturation, with As:S ratios varying from dimorphite $\left(\mathrm{As}_{4} \mathrm{~S}_{3}\right)$ to duranusite $\left(\mathrm{As}_{4} \mathrm{~S}\right)$, presenting photoactive properties [28]. However, such experiments were performed either in single strain cultures and/or using synthetic media, which cannot be easily transferred on-site. In addition, the formation 
mechanisms of As-bearing sulfides in such systems remain poorly documented. In particular, the factors governing the respective contributions of $\mathrm{As}^{\mathrm{III}}{ }_{2} \mathrm{~S}_{3}$ and $\mathrm{As}{ }^{\mathrm{II}} \mathrm{S}$ are not elucidated yet. Furthermore, no studies have aimed at removing As from bulk acid AMD water utilizing an indigenous SRB consortium, which represents a key step for implementing a PBS onsite. In this study, we took advantages of the well-documented AMD site of Carnoulès $[4,9,10,12$, 29] for sampling reduced $\mathrm{Fe}^{\mathrm{II}} / \mathrm{As}^{\mathrm{III}}$-rich waters and to isolate a SRB consortium. We performed batch experiments to evaluate the potential of biogenic sulfides as As scavengers and monitoring of microbial growth and water chemistry showed a complete removal of arsenic and zinc from solution. Moreover, the process efficiency could be linked to the identity of the arsenic sulfide minerals that successively formed during the incubation process, and which were quantitatively determined by Extended X-ray Absorption Fine Structure spectroscopy (EXAFS).

\section{Experimental}

\subsection{Batch experiments}

Enrichment of an indigenous SRB consortium. A SRB consortium reducing sulfate at $\mathrm{pH}$ 4.5 was enriched from surface sediments of the Carnoulès AMD sampled 30 m downstream the tailing impoundment, using a basal medium described in [30], but with $100 \mathrm{mg} / \mathrm{L} \mathrm{As}{ }^{\text {III }}$ (1.33 mM) instead of $\mathrm{As}^{\mathrm{V}}$ (Table SI-1). After one month of sub-culturing in this medium (once a week), the enrichment was inoculated in penicillin flasks containing a synthetic AMD medium (Table SI-2), mimicking the Carnoulès AMD composition. The BSR-SC3 pH 4.5 enrichment was sub-cultured once a week in the synthetic AMD medium, before inoculation 
in real AMD water. Sub-cultures were performed in an anaerobic chamber, inoculating at $10 \%(\mathrm{v} / \mathrm{v})$ and incubating the cultures at $25^{\circ} \mathrm{C}$ in static condition.

Incubation experiments in AMD water. Four batch experiments were performed within an anaerobic chamber, using sterile $1 \mathrm{~L} \mathrm{Schott}{ }^{\circledR}$ Bottles equipped with rubber stoppers. The biotic experiment was triplicated, with a single abiotic control experiment. AMD water was sampled at Carnoulès in July 2014 at the base of the dam and stored at $5^{\circ} \mathrm{C}$ under $\mathrm{N}_{2}$ atmosphere until utilization. The initial $\mathrm{pH}$ of 3 was adjusted to 4 by adding $\mathrm{NaOH} 1 \mathrm{M}$ in oxygen-free ultrapure water, this $\mathrm{pH}$ value being within the range of observed values at the AMD spring [12]. The bulk water was then filtered through $0.45 \mu \mathrm{m}$ filters and analyzed for chemical composition according to sampling procedure reported in section 2.2 (Table SI-3). For the control experiment, AMD water was filtered through $0.22 \mu \mathrm{m}$ filters to remove all bacteria. Prior to inoculation, each of the four batches consisted of $440 \mathrm{~mL}$ of filtered AMD water plus glycerol $(0.5 \mathrm{~g} / \mathrm{L}), \mathrm{NH}_{4} \mathrm{Cl}(0.2 \mathrm{~g} / \mathrm{L})$, and $\mathrm{K}_{2} \mathrm{PO}_{4}(0.05 \mathrm{~g} / \mathrm{L})$. Each batch $(\mathrm{B} 1, \mathrm{~B} 2$ and B3 experiments) was inoculated with $40 \mathrm{~mL}$ of BSR SC3 $\mathrm{pH} 4.5$ culture, whereas $40 \mathrm{~mL}$ of autoclaved inoculum plus $100 \mu \mathrm{L}$ formaldehyde (37\%) were added into the abiotic control experiment. The $\mathrm{N}_{2}$ pressure in the bottles was adjusted to 1.5 bar, and experiments were dark incubated at $25^{\circ} \mathrm{C}$ in static conditions for 94 days.

\subsection{Sampling procedures and microbiological analyses.}

All sampling operations described hereafter were performed in anaerobic chamber. For chemical analyses of the AMD water ( $\mathrm{pH} 4.5$ filtered) as well as for the solutions at the start and end of the experiments, $50 \mathrm{~mL}$ of suspension was sampled in each batch and filtered through $0.45 \mu \mathrm{m}$ filters. Half of this volume was acidified before analyzing cations ( $\mathrm{Ca}, \mathrm{Mg}$, 
$\mathrm{Na}, \mathrm{K}, \mathrm{NH}_{4}$, and trace elements), and half was used to analyze anions $\left(\mathrm{SO}_{4}{ }^{2-}, \mathrm{Cl}^{-}, \mathrm{PO}_{4}{ }^{3-}, \mathrm{NO}_{3}{ }^{-}\right.$, $\mathrm{NO}_{2}^{-}$) (Table SI-3).

In addition, eleven times over a period of 94 days, $10 \mathrm{~mL}$ of suspension were sampled using syringes and needles. The pH was measured with a WTW Multi3420 pH-meter. 9 mL were filtered through $0.22 \mu \mathrm{m}$ filters. The filters, covered with particulate materials were stored at $5^{\circ} \mathrm{C}$ in glass tubes under $\mathrm{N}_{2}$, and dried within the anoxic chamber. $3 \mathrm{~mL}$ of filtered water were used for dissolved sulfide measurements, $3 \mathrm{~mL}$ were frozen for organic carbon and acetate analyses, and the remaining $3 \mathrm{~mL}$ were acidified with $\mathrm{HNO}_{3}$ for $\mathrm{As}, \mathrm{Zn}$ and $\mathrm{Fe}$ analyses. One $\mathrm{mL}$ of bulk solution was devoted to bacterial cells enumeration using a Thoma cell and an optical microscope (Zeiss AxioImager, x400 magnification).

Eventually, liquid aliquots were sampled for As speciation measurements at $\mathrm{t}=0,14$ and 94 days: $5 \mathrm{ml}$ were filtered at $0.22 \mu \mathrm{m}$, frozen in liquid nitrogen and stored at $-20^{\circ} \mathrm{C}$ in glass tubes under $\mathrm{N}_{2}$ atmosphere until analysis.

At the end of the experiment, solids were settled and the supernatant was removed. The remaining suspensions were treated with $0.5 \mathrm{~mL}$ formaldehyde (37\%) and stored under $\mathrm{N}_{2}$ at $5^{\circ} \mathrm{C}$. Solids were centrifuged and washed with $\mathrm{O}_{2}$-free milliQ water before being dried under vacuum in an anaerobic chamber.

Bacterial biomass was recovered by filtration upon $0.22 \mu \mathrm{m}$ filters to evaluate the final bacterial diversity. Genomic DNAs were extracted from the filters using the FastDNA Spin Kit for Soils (Bio 101). The structure of the bacterial community was determined by Capillary Electrophoresis Single-Strand Conformation Polymorphism (CE-SSCP), as described in [26]. Peaks were assigned to a 16S rRNA gene sequence by comparison with the migration patterns of the sequence of two individual clones, Propionibacteraceae sp. H7p and a Desulfosporosinus sp., obtained by cloning and sequencing of 16S rRNA gene retrieved from the inoculum. 


\subsection{Liquid samples analysis}

Dissolved sulfides $(0.01-1.50 \mathrm{mg} / \mathrm{l})$ were quantified with the Spectroquant Merk $^{\mathrm{TM}}$ colorimetric method (methylene blue).

Total dissolved As, $\mathrm{Zn}$ and Fe were analyzed with a graphite furnace atomic absorption spectrophotometer (GF-AAS, Varian, Palo Alto, CA, USA).

Organic carbon and acetate were analyzed by ionic chromatography (Dionex -ICS 3000).

Anions and cations were quantified by ionic chromatography (ICS 3000: with a AS 15 Dionex 4 mm column and Metrohm: Compact IC 8814 mm column, respectively).

Arsenic speciation in the initially frozen liquid samples was determined by High Performance Liquid Chromatography (SpectraSystem P4000, ThermoFisher Scientific) coupled to Hydride Generation and an ICP-MS, X Series II (ThermoFisher Scientific) according to [31, 32] as detailed in SI-Experimental part.

\subsection{Solid samples analysis}

X-Ray diffraction (XRD). XRD measurements were performed under anoxic conditions with Co K $\alpha$ radiation using a Panalytical X'Pert Pro diffractometer. Within an anaerobic chamber, powder samples were resuspended in ethanol, deposited on a silicon single-crystal lowbackground sample holder and placed into the anoxic sample chamber. Data were collected in continuous mode between 5 and $80{ }^{\circ} 2 \theta$ with a $0.033^{\circ} 2 \theta$ step, counting $\sim 4$ hours per sample.

Electron microscopy. Morphology of the biofilms was observed using a Field Emission Gun Scanning Electron Microscope (GEMINI ZEISS Ultra55) operating at $15 \mathrm{kV}$. Observations were performed either using secondary electron or backscattered electron signals. Energy 
Dispersive X-Ray Spectroscopy (EDXS) measurements were performed at selected spots, probing approximately $1 \mu \mathrm{m}^{3}$ volumes.

Transmission Electron Microscopy (TEM) measurements were performed using a JEOL Field Emission Gun 2100F instrument, operating at $200 \mathrm{kV}$. Samples were suspended in $\mathrm{O}_{2}$-free ethanol and sonicated for 5 minutes before one drop of the mix was deposited on a carboncoated grid. EDXS measurements were performed with various spot sizes $(500-50 \mathrm{~nm})$ depending of the size of the objects to analyze, and using a minimum counting time of 30 seconds.

\section{Extended X-Ray Absorption Fine Structure (EXAFS) spectroscopy}

Model compounds. A set of As-sulfide references was analyzed, including Thiol-bound As ${ }^{\text {III }}$ $\left(\mathrm{As} \_(\mathrm{Glu})_{3}\right)$, amorphous orpiment $\left(\mathrm{am}-\mathrm{As}_{2} \mathrm{~S}_{3}\right)$, crystalline orpiment $\left(\mathrm{As}_{2} \mathrm{~S}_{3}\right)$ and crystalline realgar (AsS). Both crystalline orpiment and realgar were obtained from the IMPMC mineral collection. Amorphous orpiment was synthesized by progressive addition of concentrated $\mathrm{HCl}$ to a solution containing $\mathrm{As}^{\mathrm{III}}\left(0.1 \mathrm{M}, \mathrm{NaAsO}_{2}\right)$ and dissolved sulfide $\left(0.625 \mathrm{M}, \mathrm{Na}_{2} \mathrm{~S}-9 \mathrm{H}_{2} \mathrm{O}\right)$. As ${ }^{\mathrm{III}}$-sorbed ferrihydrite with surface coverage of $0.22 \mu \mathrm{mol} . \mathrm{m}^{-2}$ [33] and $\mathrm{As}^{\mathrm{V}}{ }^{\mathrm{S}}$-sorbed ferrihydrite with surface coverage of $1.05 \mu$ mol.m ${ }^{-2}$ (Fig SI-5), were used as model compound for $\mathrm{As}^{\mathrm{V}}$ and $\mathrm{As}^{\mathrm{III}}$ coordinated to an oxygen first shell. $\mathrm{As}^{\mathrm{V}}$-substituted amorphous aluminum phosphate was synthesized as a model compound relevant to minor $\mathrm{As}(\mathrm{V})$ phases observed by SEM in the incubation samples. EXAFS data of these model compounds were either compared to theoretical spectra calculated using the Feff8.1 code [34] or were fit using a shell-by-shell procedure. Crystal structures were taken from $[35,36]$ for orpiment and realgar, respectively. For shell-by-shell fitting of $\mathrm{As}^{\mathrm{III}}$ - and $\mathrm{As}^{\mathrm{V}}$-sorbed ferrihydrites, phase-shift and amplitude functions for the As-O, As-O-O and As-Fe scattering paths were calculated on the 
basis of the structures of scorodite [37] and tooeleite [38], using Feff8.1 with the self consistent potential option. Results are plotted in Figure SI-1 and corresponding parameters are given in Tables SI-4 and SI-5.

Data collection and analysis. As K-edge EXAFS spectra of As-sulfides model compounds were collected at $15 \mathrm{~K}$ in transmission mode on the SAMBA beamline (SOLEIL, Saint-Aubin, France) using a $\mathrm{Si}(220)$ double-crystal monochromator. As K-edge EXAFS spectra for the biofilms samples were recorded at $80 \mathrm{~K}$ in transmission mode on the XAFS beamline (ELETTRA, Trieste, Italy) using a Si(111) double-crystal monochromator. To preserve As redox, samples were mounted on the cryostat sample rod within a glovebox and quickly transferred into the cryostat. The incident beam energy was calibrated by setting to $11947 \mathrm{eV}$ the energy position of the absorption maximum in the $\mathrm{L}_{\mathrm{III}}$-edge of an $\mathrm{Au}$ foil recorded in double-transmission. 2-5 scans were recorded depending on As concentrations. Scans were averaged, normalized and background subtracted over the $0-13 \AA^{-1} k$-range using the Athena Software [39]. Linear combination fitting (LCF) of EXAFS data were performed on $k^{3}$ weighted curves over the $3-13 \AA^{-1} k$-range .

\section{Results}

\subsection{Evolution of water chemistry in the incubation experiments}

Total As and $\mathrm{Zn}$ removal from the solution was observed for B1 and B2 within the 94 days of the experiment whereas for B3, only half of the initial As and $\mathrm{Zn}$ was removed (Figure 1; Table SI-3). Neither As nor Zn removal was detected in the abiotic control experiment. Three stages could be distinguished in the experiments: (i) During the first 14 days, $73-87 \%$ As and 
18-28 \% of Zn precipitated in B1 and B3, whereas a delay was observed for B2; (ii) From 14 to 49 days, total precipitation of As and $\mathrm{Zn}$ was observed in B2, whereas the dissolved As and Zn concentrations slightly increased in B1 and B3; (iii) During the 49-94 days period, As and

Zn concentrations decreased below detection limit in B1, whereas they remained stable in B3 (above 0.4 and $0.08 \mathrm{mmol} / \mathrm{L}$, respectively). During this last period, values remained close to zero in B2, suggesting irreversible precipitation of $\mathrm{As}$ and $\mathrm{Zn}$ in this batch. Finally, important Fe uptake was observed in B2 (from 16.5 to $13.8 \mathrm{mmol} / \mathrm{L}$ ), whereas it was moderate in $\mathrm{B} 1$ (from 16.5 to $15.6 \mathrm{mmol} / \mathrm{L}$ ) and absent in $\mathrm{B} 3$.

Dissolved concentrations of $\mathrm{Na}, \mathrm{Mg}, \mathrm{K}, \mathrm{Mn}$ and $\mathrm{Ca}$ concentrations only slightly varied during the 0-94 days experiment, whereas $\mathrm{Al}$ concentrations decreased, indicating its precipitation (Table SI-3). pH variations along the experiments can also be described according to the stages defined previously: a first stage of $\mathrm{pH}$ rising from 4 to 4.7 is identified during the first 20 days with the same delay for B2 as observed for As and Zn removal. During a second stage, $\mathrm{pH}$ remained stable around 4.7 for $\mathrm{B} 1$ and $\mathrm{B} 3$ while it increased in $\mathrm{B} 2$ to stabilize around 5.

Measurements of As speciation in solution (Table SI-6) indicated the predominance of arsenate and arsenite species until low As concentrations were reached ( $t=94$ days). At the end of experiments, S-bound dissolved As-species were detected, in the forms of arsenite, mono-, di- and tri-thioarsenates. Such species possibly result from the oxidation of thioarsenites during analysis [31].

\subsection{Microbial activity}

Microbial growth, evaluated by cell counting, attested the existence of bacterial activity, and exhibited a comparable magnitude in the triplicates (Figure 1). Importantly, no growth 
occurred in the control batch. From 0 to 14 days, the development of microorganisms was observed in B1 and B3. For B2, the increase in cell number was delayed to the 14-49 days period, consistently with the delay observed in the decrease of As and $\mathrm{Zn}$ concentrations. During the 49-94 days period, the number of cells stabilized in B3 and started to decrease in B1 and B2 experiments, in which total As and Zn removal was observed.

SRB produce dissolved sulfides (Figure SI-2; Table SI-3) from the reduction of sulfate and consumption of glycerol in solution, this latter acting both as carbon source and electron donor. This process results in either acetate or $\mathrm{CO}_{2}$ production depending on the SRB strains. The highest concentration of $\mathrm{CO}_{2}$ in the gaseous phase (Figure SI-2) was observed for B2 at day $63\left(\left[\mathrm{CO}_{2}\right]=0.5 \mathrm{mmol} / \mathrm{L}\right)$. Simultaneously, high acetate concentrations were observed in the liquid phase ([acetate]finalB2 $=10 \mathrm{mmol} / \mathrm{L}$, Figure 2 ). At $\mathrm{pH} 4-5, \mathrm{CO}_{2}$ is mainly present as $\mathrm{H}_{2} \mathrm{CO}_{3}$ in solution, which implies that $\mathrm{CO}_{2}$ measured as gas only account for a part of the mineralized carbon. This is consistent with both $\mathrm{CO}_{2}$ and acetate production by this consortium, showing that it contains incomplete oxidizers. The bacterial community structure assessed by CE-SSCP showed no noticeable divergence of the microbial diversity at the end of each experiment (Figure SI-3). It confirmed the presence a Propionibacteraceae bacterium closely related to a strain previously isolated at acidic $\mathrm{pH}$ at the Carnoulès AMD [40], its function being unknown to date, and a Desulfosporosinus strain. Several members of this latter genus are known to incompletely reduce sulfate at acidic $\mathrm{pH}[23,24]$, i.e. producing both acetate and $\mathrm{CO}_{2}$ from organic substrates, as observed in our experiments. Desulfosporosinus orientis has been also identified as SRB strain involved in experimental in situ remediation of acidic contaminated groundwaters [22]

To quantify sulfate-reduction activity, both $\mathrm{SO}_{4}{ }^{2-}$ consumption and acetate production rates were compared within the 94 days of experiment (Table SI-3). Sulfate-reducing activity was observed to be the highest in B2, intermediate in B1, and the lowest in B3. This gradient of 
sulfate reduction is in agreement with the removal rate of total $\mathrm{S}$ observed, i.e. 3.94, 5.31, and $1.72 \mathrm{mmol} / \mathrm{L}$ for $\mathrm{B} 1, \mathrm{~B} 2$ and $\mathrm{B} 3$ respectively (Table SI-7). This difference in microbial activity is also supported by the difference in sulfide production rate estimated either from the sum of As, $\mathrm{Zn}$ and Fe removal rate in the form of sulfides from solution (2.10, 3.55 and 1.16 $\mathrm{mmol} / \mathrm{L}$ equivalent $\mathrm{S}$ for $\mathrm{B} 1, \mathrm{~B} 2$ and $\mathrm{B} 3$ ) or from metal concentrations in the final solids (1.70, 2.60 and $1.10 \mathrm{mmol} / \mathrm{L}$ equivalent S for B1, B2 and B3) (Table SI-7, Table SI-8). Such differences in sulfide production observed between B1, B2 and B3 could possibly result from differences in the respective evolution of bacterial communities within the consortium during the experiments.

\subsection{Arsenic and zinc speciation in the biofilms}

X-ray diffraction performed on the solid recovered at the end of batch experiments revealed that precipitates mostly consisted of amorphous or nano-sized materials (Figure SI-4). Only a weak peak was observed for B1 and B2, assigned to the (100) Bragg reflexion of $\beta$-realgar [41]. This is consistent with the results of EXAFS LCF analysis that indicated 29-34\% of realgar (AsS) in B1 and B2 final solids, respectively (Table 1; Figure 2). Electron microscopy confirmed the presence of realgar in these biofilms in the form of nanowire-like structures (Figure 3). EXAFS-LCF also revealed major amounts of S-bound trivalent arsenic in B1, B2 and B3, in the form of amorphous orpiment (am-As $\left.{ }_{2}{ }_{2} \mathrm{~S}_{3}\right)$ and thiol-bound $\mathrm{As}{ }^{\mathrm{III}}$, accounting for 33-73\% and 13-23\% of total As, respectively (Table 1; Figure 2). Electron microscopy did not permit to observe these two latter species as isolated particles. However, TEM-EDXS microanalyses showed prevalent As and S signals for numerous particles and aggregates (Figure SI-5), suggesting that S-bound trivalent As species were dispersed in the biofilm. 
Besides, in all the solid samples studied, As-bearing Al-P-S rich spherical aggregates were observed by TEM/SEM-EDXS (Figure 2, Figure SI-5), whose composition has been reported elsewhere as APS (aluminum phosphate-sulfate, [42, 43]). They are possible host for $\mathrm{AsO}_{4}$ since it commonly substitutes for $\mathrm{PO}_{4}$ [44]. As the AMD is Al-rich, these particles could likely have precipitated from $\mathrm{K}_{2} \mathrm{PO}_{4}$ added in the medium prior to inoculation. The presence of such particles was consistent with the minor contribution of $\mathrm{As}^{\mathrm{V}}$ in the biofilms $(9-13 \%$; Table 1; Figure 2). A minor contribution from arsenite (As ${ }^{\mathrm{III}}-\mathrm{O}$ bonding) was observed in the solids collected on filters at days 14 and 49 in the B1 experiment, and in the solids of the abiotic control. Such contribution could result from incomplete sulfidization of the large amount of arsenious acid initially present in the AMD (0.9 mmol/L, Table SI-3).

Finally, EXAFS at the Zn K-edge showed that Zn was mainly present as amorphous ZnS, consistently with TEM-EDXS observation of $\mathrm{ZnS}$ nanoparticles (Figure SI-6) presenting shapes and sizes relevant for biogenic $\mathrm{ZnS}$ precipitation [45].

\section{Discussion}

\subsection{Sulfate-reducing activity and sulfide formation}

According to our observations, the main reaction involved at $\mathrm{pH} 5$ concerning the sulfatereduction activity of the consortium was the incomplete oxidation of glycerol, here taken from [46] and adapted to acidic $\mathrm{pH}$ :

$$
\mathrm{C}_{3} \mathrm{H}_{8} \mathrm{O}_{3}+0.75 \mathrm{SO}_{4}{ }^{2-}+1.5 \mathrm{H}^{+}=\mathrm{C}_{2} \mathrm{H}_{4} \mathrm{O}_{2}+\mathrm{H}_{2} \mathrm{CO}_{3}+0.75 \mathrm{H}_{2} \mathrm{~S}+\mathrm{H}_{2} \mathrm{O}
$$

Mass balance of S applied to both the liquid and solid phases (Table SI-7) indicated that a non negligible part of $S$ in the solid phase was not incorporated into As/Zn/Fe-sulfide minerals. 
Such difference could be explained by the additional precipitation of organic-S and $\mathrm{S}^{0} /$ polysulfides, consistently with the observation of S-rich particles using electron microscopy (Figure SI-5).

The presence of $\mathrm{As}_{2} \mathrm{~S}_{3(\mathrm{am})}$ and $\mathrm{ZnS}_{(\mathrm{am})}$ in the precipitates was evidenced by bulk X-Ray absorption spectroscopy (Figure 2, Figure SI-6), and FeS particles were observed using TEM imaging (Figure SI-7). In addition, no crystalline phase was detected in XRD pattern except minute amounts of realgar in B1 and B2. Thus the main part of these minerals can be considered as amorphous. Accordingly, the following precipitation reactions were the most likely to occur:

$$
\begin{aligned}
& 2 \mathrm{H}_{3} \mathrm{AsO}_{3}+3 \mathrm{H}_{2} \mathrm{~S}=\mathrm{As}_{2} \mathrm{~S}_{3(\mathrm{am})}+6 \mathrm{H}_{2} \mathrm{O} \\
& \mathrm{Zn}^{2+}+\mathrm{H}_{2} \mathrm{~S}=\mathrm{ZnS}_{(\mathrm{am})}+2 \mathrm{H}^{+} \\
& \mathrm{Fe}^{2+}+\mathrm{H}_{2} \mathrm{~S}=\mathrm{FeS}_{(\mathrm{am})}+2 \mathrm{H}^{+}
\end{aligned}
$$

In $\mathrm{B} 2$ and $\mathrm{B} 1$, in which the sulfide production was the highest, concomitant As and $\mathrm{Zn}$ precipitation was observed (0-49 days), and Fe precipitation occurred after total As and $\mathrm{Zn}$ removal (49-94 days) (Figure 1). Considering the $\mathrm{pH}, \mathrm{As}, \mathrm{Zn}$ and Fe concentrations, and a theoretical $\mathrm{H}_{2} \mathrm{~S}$ concentration of $0.004 \mathrm{mM}$, the saturation indexes (SI) were calculated and compared for the solid phases forming from reactions (2), (3) and (4). Results of this simulation were overall consistent with the order of sulfide precipitation observed: $\mathrm{As}_{2} \mathrm{~S}_{3}(\mathrm{am})$ $>\mathrm{ZnS}_{(\mathrm{am})}>\mathrm{FeS}_{(\mathrm{am})}$ (Figure SI-8). Besides, simultaneous precipitation of As and $\mathrm{Zn}$ is not surprising since it was already observed in a biochemical reactor system [27], where Zn was assumed to improve As removal rate, possibly by consuming the excess of dissolved sulfide, 
avoiding orpiment dissolution to soluble thioarsenites. Finally, $\mathrm{Fe}$ removal at the end suggested a shift towards (4), in agreement with the evolution of SI values (Figure SI-8).

\subsection{Precipitation of $S$-bound As-bearing species}

Sulfur-bound trivalent As. In agreement with previous studies [13, 14, 26, 27, 28], EXAFSLCF showed that amorphous orpiment was the main mineral resulting from the interaction of arsenic with biogenic sulfides. This mineral is the most likely to precipitate at acidic $\mathrm{pH}(<$ 5.5) since its production is kinetically favored with respect to crystalline orpiment [47]. As biofilms are multi-component materials, electron microscopy failed at revealing pure $\mathrm{As}_{2} \mathrm{~S}_{3}$ particles but $\mathrm{S}$ and As X-ray emission lines were detected in aggregates or on mineralized cells, which would be consistent with the observations of Newman et al. [13] of both intraand extracellular monodisperse $50-100 \mathrm{~nm}$ particles. In another study by Lee et al. [28], amorphous orpiment was identified as filaments of 20-100 nm diameter, presumably deriving from biofilm EPS. Here, the filamentous structures that exhibited strong electron backscattering signal were probed by EDXS to have a realgar (AsS) composition, although coatings of nanosized $\mathrm{As}_{2} \mathrm{~S}_{3}$ particles were observed on some AsS filaments by TEM.

Including a thiol-bound $A s^{\mathrm{III}}$ component in the EXAFS-LCF improved the fit quality. The presence of this species, that has not been reported yet in studies concerning similar systems would not be surprising since the SRB-related biomass contains thiol functions, well-known for their high affinity for As ${ }^{\mathrm{III}}$ [48]. This would be consistent with the organic-S component that must be invoked to explain S mass balance results (Table SI-7). Thiol-bound As ${ }^{\mathrm{III}}$ could have previously been overlooked due to its high dispersion in the biofilm and to the close XAS spectral features that it shares with amorphous $\mathrm{As}_{2} \mathrm{~S}_{3}$ (Figure SI-9). 
Realgar (AsS). Realgar was detected in B1 and B2 with a contribution of 29-34 \% after 94 days of experiment, whereas only orpiment was detected in the B3 experiment in which the sulfide production was the lowest. The occurrence of realgar in similar contexts was recently reported on the basis of XAS measurements by Rodriguez-Freire et al. [16, 17] at circumneutral $\mathrm{pH}$ and by Jackson et al. [27] in acidic conditions. In these studies, the formation of AsS was attributed to the maturation of $\mathrm{As}_{2} \mathrm{~S}_{3}$, as initially suggested by Lee et al. [28], but no mechanism has been proposed for this mineral transformation. On the basis of TEM-EDXS analysis of nanotube cross-sections, Lee et al. invoked the maturation of amorphous orpiment to As-S nanotubes presumably composed of various As-sulfides, ranging from realgar to duranusite $\left(\mathrm{As}_{4} \mathrm{~S}\right)$. Here, no composition with As:S ratio higher than 1:1 was observed by TEM-EDXS, according to comparison with reference minerals (Figure 3). In a SRB consortium sampled from Andean salt flats deposits, precipitation of AsS fibers were also observed [14].

\subsection{From amorphous orpiment to realgar nanowires}

Several studies have reported the concomitant occurrence of orpiment and realgar minerals in experiments, either derived from the action of isolated SRB strains $[16,17,28]$ or from SRB consortia [14, 27]. Besides, another SRB strain was found to selectively precipitate amorphous orpiment [13] and only one study has reported the selective precipitation of biogenic $\beta$-realgar at higher temperature by arsenic metabolizing thermophilic bacterium from the Murky Pot hot spring [49]. Considering these studies, direct biogenic precipitation of realgar fibers from dissolved $\mathrm{As}^{\mathrm{III}}$ seems unlikely since a step of reduction of $\mathrm{As}^{\mathrm{III}}$ is needed to form As ${ }^{\mathrm{II}} \mathrm{S}$. Accordingly, at $\mathrm{pH}$, the stability field of realgar occurs at lower Eh values than orpiment (Fig SI-10A, [28]). Additionally, As speciation in B1 at day 14 indicated that no AsS had formed, even if $73 \%$ of As had precipitated in the form of amorphous orpiment. 
Within the biofilm, realgar was detected at distance from the cells, consistently with Demergasso et al. [14], and no realgar encrusted bacteria were found, as in Ledbetter et al. [49]. This supports the fact that realgar did not form via direct interaction of dissolved As ${ }^{\text {III }}$ with biogenic dissolved sulfide. In the samples, mineralized cells returned As and S EDXS signals consistent with local precipitation of orpiment, as previously observed for SRB [13, 14]. Consequently, we propose that amorphous orpiment aggregates first formed by the precipitation of $A s^{I I I}$ with biogenic sulfide. Then transformation of amorphous orpiment into crystalline realgar implies the reduction of $\mathrm{As}^{\mathrm{III}}$ to $\mathrm{As}^{\mathrm{II}}$. In the absence of reductant, this would have resulted in orpiment disproportionation:

$$
\mathrm{As}^{\mathrm{III}}{ }_{2} \mathrm{~S}_{3}=2 \mathrm{As}{ }^{\mathrm{II}} \mathrm{S}+\mathrm{S}^{0}
$$

However, such disproportionation reaction is not thermodynamically favored (Fig. SI-10) in our experimental conditions. In contrast, reduction of orpiment to realgar would rather be driven by biogenic $\mathrm{H}_{2} \mathrm{~S}$ (Fig. SI-10B):

$$
\mathrm{As}_{2}{ }_{2} \mathrm{~S}_{3}+\mathrm{H}_{2} \mathrm{~S}=2 \mathrm{As}^{\mathrm{II}} \mathrm{S}+\mathrm{H}_{2} \mathrm{~S}_{2}
$$

As $\mathrm{H}_{2} \mathrm{~S}$ activity implies the formation of polysulfide ions, such as for instance $\mathrm{H}_{2} \mathrm{~S}_{2}$, even in the absence of elemental sulfur [50], they are likely to be produced by (6), as they are stable between the $\mathrm{H}_{2} \mathrm{~S}$ and $\mathrm{S}^{0}$ stability fields (Fig. SI-10B).

Thus, reaction (6) would have been maintained overtime in B1 and B2 by continuous production of biogenic $\mathrm{H}_{2} \mathrm{~S}$, increasing the amount of $\mathrm{AsS}$ with respect to $\mathrm{As}_{2} \mathrm{~S}_{3}$ after total As and $\mathrm{Zn}$ precipitation. The absence of realgar in B3 is thus explained by the low sulfide production in this experiment. Additionally, as $\mathrm{Fe}^{\mathrm{II}}$ was present in solution, precipitation of 
$\mathrm{FeS}_{(\mathrm{am})}$ as detailed in (4) could also have contributed to regulate $\mathrm{H}_{2} \mathrm{~S}$ activity. For instance, in batch experiments at pH 6.1 but with no iron or zinc in solution, Rodriguez-Freire et al. [17] also observed a mix of orpiment and realgar.

Soluble thio-As species detected in B1 and B2, but not in B3, likely resulted from As interaction with sulfide when increasing the S/As ratio [51]. In particular, considering our $\mathrm{pH}$ conditions (4.5-5) and dissolved sulfide concentrations $(<0.0003 \mathrm{mmol} / \mathrm{L})$, orpiment is expected to partly dissolve into soluble trithioarsenite according to thermodynamic calculation [51, 52], which could be written as follows:

$$
\mathrm{As}^{\mathrm{III}}{ }_{2} \mathrm{~S}_{3}+3 \mathrm{H}_{2} \mathrm{~S}=2 \mathrm{As}^{\mathrm{III}}(\mathrm{SH})_{3}
$$

Moreover, an equilibrium between trithioarsenites and realgar could also be envisaged:

$$
2 \mathrm{As}^{\mathrm{II}} \mathrm{S}+2 \mathrm{H}_{2} \mathrm{~S}+\mathrm{H}_{2} \mathrm{~S}_{2}=2 \mathrm{As}^{\mathrm{III}}(\mathrm{SH})_{3}
$$

These assumptions raise the question of whether orpiment to realgar transformation occurs via a solid state mechanism or via dissolution/precipitation involving thio-As as soluble intermediates, this latter process being supported by the presence of such thio-As species in our experiments.

Regarding the origin of realgar nanowires, Lee et al. [28] hypothesized that $\mathrm{As}_{2} \mathrm{~S}_{3}$ already exhibited a filament shape before transforming into AsS and polycrystalline As-S nanotubes. Here, no $\mathrm{As}_{2} \mathrm{~S}_{3}$ filaments were observed and orpiment rather occurred as finely dispersed particles and as coatings around bacterial cells (Figure 3). Within the biofilm, besides AsS nanowires, multiple filaments presenting polydisperse diameters $(50-200 \mathrm{~nm})$ constituted of light elements under SEM observation in backscattering mode were observed (Figure SI-11). 
They are interpreted as exopolymeric substances that could possibly act as templates for AsS nanowire formation.

In this bioremediation process, realgar appears as the most efficient host phase for arsenic scavenging since this phase presents a higher As:S ratio than orpiment. In addition, as AsS exhibits a crystalline form, it is possibly less sensitive to dissolution. However, it is sensitive to light and to oxygen, which represents constraints that should be addressed for storing and recycling the products of a passive anaerobic bioremediation system.

\section{Conclusion}

This study shows that it is possible to totally remove dissolved arsenic from one of the most As-rich AMD in France, via incubations with an indigenous SRB consortium. We infer that this process can be considered as a promising mean to mitigate As concentrations at highly contaminated AMD sites, for instance by stimulating the activity of indigenous SRB consortia. Arsenic first precipitated as amorphous orpiment $\left(\mathrm{As}_{2}^{\mathrm{III}} \mathrm{S}_{3}\right)$ that further transformed into As ${ }^{\mathrm{II}} \mathrm{S}$ nanowires. We propose that this transformation relies on the continuous production of $\mathrm{H}_{2} \mathrm{~S}$ by $\mathrm{SRB}$, driving $\mathrm{As}_{2} \mathrm{~S}_{3}$ reduction into crystalline realgar, likeky involving aqueous trithioarsenite species intermediate. Crystalline realgar thus likely represents a reliable arsenic host in SRB-mediated remediation systems applied to arsenic-rich AMD.

\section{Aknowledgements}

This research was financially supported by the French ANR IngECOST-DMA. Imène Estève, Benoit Baptiste and Ludovic Delbes are acknowledged for providing instrumental support at the SEM-EDX and XRD facilities. Gautier Landrot, Emiliano Fonda and Andrea Zitolo from 
the SAMBA beamline at SOLEIL are acknowledged for their help in the measurement of references compounds at the As K-edge. 


\section{References}

[1] Mitchell V. L. (2014) Health risks associated with chronic exposures to arsenic in the environment. Reviews in Mineralogy and geochemistry 79, 435-449.

[2] Basta, N. T., Juhasz A. (2014) Using in vivo bioavailability and/or in vitro gastrointestinal bioaccessibility testing to adjust human exposure to arsenic from soil ingestion. Reviews in Mineralogy and geochemistry 79, 451-472.

[3] Morin G., and Calas G. (2006) Arsenic in soils, mine tailings, and former industrial sites. Elements 2 (2), 97-101.

[4] Casiot C., Lebrun S., Morin G., Bruneel O., Personné J. C., Elbaz-Poulichet F. (2005) Sorption and redox processes controlling arsenic fate and transport in a stream impacted by acid mine drainage. Science of the Total Environment 347, 122-130.

[5] Sarmiento A. M., DelValls A., Nieto J. M. Salamanca M. J., Caraballo M. A. (2011) Toxicity and potential risk assessment of a river polluted by acid mine drainage in the Iberian Pyrite Belt (SW Spain). Science of the Total Environment 409, 4763-4771.

[6] Johnson, D.B., and Hallberg, K.B. (2005) Acid mine drainage remediation options: a review. Science of the total environment, 338 (1-2), 3-14.

[7] Palfy, P., Vircikova, E., Molnar, L., (1999) Processing of arsenic waste by precipitation and solidification. Waste Manag. 19, 55-9.

[8] Carlson L., Bigham J. M., Schwertmann U., Kyek A. and Wagner F. (2002) Scavenging of As from acid mine drainage by schwertmannite and ferrihydrite: a comparison with synthetic analogues. Environ. Sci. Technol. 36, 1712-1719.

[9] Morin G., Casiot C., Bruneel O., Personne JC., Elbaz-Poulichet F., Leblanc M., Ildefonse P., and Calas G. (2003) Bacterial formation of tooeleite and mixed Arsenic(III) or Arsenic(V)-Iron(III) gels in the carnoules acid mine drainage, France. 
A XANES, XRD and SEM study. Environmental Science \& Technology 37 (9), 1705 1712.

[10] Maillot F., Morin G., Juillot F., Bruneel O., Casiot C., Ona-Nguema G., Wang Y., Lebrun S., Aubry E., Vlaic G., Brown Jr. G.E. (2013) Structure and reactivity of As(III)- and As(V)-rich schwertmannites and amorpous ferric arsenate sulfate from the Carnoulès acid mine drainage, France: Comparison with biotic and abiotic model compounds and implications for As remediation. Geochimica et Cosmochimica Acta $104,310-329$.

[11] Egal M., Casiot C., Morin G., Parmentier M., Bruneel O., Lebrun S., Elbaz-Poulichet F. (2009). Kinetic control on the formation of tooleite, schwertmannite and jarosite by Acidithiobacillus ferroxidans strains in an As(III)-rich acid mine water. Chemical Geology 265, 432-441.

[12] Egal M., Casiot C., Morin G., Elbaz-Poulichet F., Cordier M. A. and Bruneel O. (2010) An updated insight into the natural attenuation of As concentrations in Reigous creek (southern France). Appl. Geochem. 25(12), 1949-1957.

[13] Newman D. K., Beveridge T. J., and Morel F. M. M. (1997) Precipitation of arsenic trisulfide by Desulfotomaculum auripigmentum. Applied and environmental microbiology 63(5), 2022-2028.

[14] Demergasso C. S., Guillermo C. D., Lorena E. G., Pueyo Mur J. J., and Pedros-Alio C. (2007) Microbial precipitation of arsenic sulfides in Andean salt flats. Geomicrobiology Journal 24:2, 11-123.

[15] Omoregie E. O., Couture R-M., Van Cappellen P., Corkhill C. L., Charnock J. M., Polya D. A., Vaughan D., Vanbroekhoven K., and Lloyd J. R. (2013) Arsenic bioremediation by biogenic iron oxides and sulfides. Applied and environmental microbiology 79 (14), 4325-4335 
[16] Rodriguez-Freire L., Sierra-Alvarez R., Root R., Chorover J., Field J. A. (2014) Biomineralization of arsenate to arsenic sulfides is greatly enhanced at midly acidic conditions. Water Research 66, 242-253.

[17] Rodriguez-Freire L., Moore S. E., Sierra-Alvarez R., Root R., Chorover J., Field J. A. (2015) Arsenic remediation by formation of arsenic sulfide minerals in a continuous anaerobic bioreactor. Biotechnology \& Bioengineering 113 (3), 522-530.

[18] Saunders, J.A., Lee, M-K., Shamsudduha M., Dhakal P., Uddin A., Chowdury M.T., Ahmed K.M. (2008) Geochemistry and mineralogy of arsenic in (natural) anaerobic groundwaters. Applied Geochemistry 23, 3205-3214.

[19] Kimura, S., Hallberg, K.B., Johnson, D.B. (2006) Sulfidogenesis in Low pH (3.8-4.2) Media by a Mixed Population of Acidophilic Bacteria. Biodeg. 17, 159-167.

[20] Johnson, D.B., Hallberg, K.B. (2008) Carbon, Iron and Sulfur Metabolism in Acidophilic Micro-organisms. Adv. Microbial. Physiol. 54, 201-255.

[21] Johnson, D.B., Jameson, E., Rowe, O.F., Wakerman, K., Hallberg, K.B., (2009) Sulfidogenesis at Low $\mathrm{pH}$ by Acidophilic Bacteria and its Potential for the Selective Recovery of Transition Metals from Mine Waters. Advanced Materials Research 7173, 693-696.

[22] Saunders, J.A, Lee, M-K., Wolf. L.A., Morton, C.M., Feng, Y., Thomson, I., and Park, S, 2005, Geochemical, microbiological, and geophysical assessments of anaerobic immobilization of heavy metals: Bioremediation Journal, v. 9, p. 33-48.

[23] Alazard, D., Joseph, M., Battaglia-Brunet, F., Cayol, J.-L., Ollivier, B., (2010) Desulfosporosinus acidiphilus sp. nov.: a Moderately Acidophilic Sulfate-reducing Bacterium Isolated from Acid Mining Drainage Sediments. Extremophiles. 14, 305-12. 
[24] Sanchez-Andrea I, Stams A. J. M., Hedrich S., Nancucheo I., Johnson D. B. (2015) Desulfosporosinus acididurans sp. nov.: an acidophilic sulfate-reducing bacterium isolated from acidic sediment. Extremophiles 19, 39-47.

[25] Karnachuk O. V., Mardanov A. V., Avakyan M. R., Kadnikov V. V., Vlasova M., Beletsky A. V., Gerasimchuk A. L., Ravin N. V. (2015) Draft genome sequence of the first acid-tolerant sulfate-reducing deltaproteobacterium Desulfovibrio sp. TomC having potential for minewater treatment. FEMS Microbiol Lett 2015;362:1-3

[26] Battaglia-Brunet F., Crouzet C., Burnol A., Coulon S., Morin D., Joulian C. (2012) Precipitation of arsenic sulphide from acidic water in a fixed-film bioreactor. Water Research $46: 3923-3933$.

[27] Jackson C. K., Koch I., and Reimer K. J. (2013) Mechanisms of dissolved arsenic removal by biochemical reactors: A bench- and field-scale study. Applied Geochemistry 29, 174-181.

[28] Lee J-H., Kim M-G., Yoo B., Myung N. V., Maeng J., Lee T., Dohnalkova A. C., Fredrickson J. K., Sadowsky M. J., and Hur H-G. (2007) Biogenic formation of photoactive arsenic-sulfide nanotubes by Shewanella sp. Strain HN-41.

[29] Resongles E., Casiot C., Elbaz-Poulichet F., Freydier R., Bruneel O., Piot C., Delpoux S., Volant A., and Desoeuvre A. (2013). Fate of $\mathrm{Sb}(\mathrm{V})$ and $\mathrm{Sb}(\mathrm{III})$ species along a gradient of $\mathrm{pH}$ and oxygen concentration in the carnoules mine waters (Souther France). Environmental Scienc-Processes \& impacts, 15 (8), 1536-1544.

[30] Battaglia-Brunet, F., Morin, D., Coulon, S., Joulian C. (2009) Bioprecipitation of Arsenic Sulphide at Low pH. Adv. Mat. Res. 71-73, 581-584.

[31] Planer-Friedrich B., Suess E., Scheinost A.C., Wallschläger, D. (2010). Arsenic Speciation in Sulfidic Waters: Reconciling Contradictory Spectroscopic and Chromatographic Evidence. Analytical Chemistry 82, 10228 - 10235. 
[32] Stauder S., Raue B., Sacher F. (2005) Thioarsenates in sulfidic waters. Environmental Science and Technology 39, $5933-5939$.

[33] Hohmann C., Morin G., Ona-Nguema, G., Guignier J-M., Brown G.E., Kappler A. (2011) Molecular-level modes of As binding to Fe(III) (oxyhydr)oxides precipitated by the anaerobic nitrate-reducing $\mathrm{Fe}(\mathrm{II})$-oxidizing Acidovorax sp strain BoFeN1. Geochimica et Cosmochimica Acta 75 (17), 4699-7412.

[34] Ankudinov A. L., Ravel B., Rehr J. J. and Conradson S. D. (1998) Real-space multiple-scattering calculation and interpretation of X-ray-absorption near-edge structure. Phys. Rev. B 58, 7565- 7576.

[35] Mullen D. J. E., and Nowacki W. (1972) Refinement of the crystal structures of realgar, AsS and orpiment, As2S3. Zeitschrift für Kristallographie - Crystalline Materials 136, 1-6.

[36] Hejni C., Sagl R., Tobbens D. M., Miletich R., Wildner M., Nasdala L., Ullrich A., and Balic-Zunic (2012) Crystal-structure properties and the molecular nature of hydrostatically compressed realgar. Phys Chem Minerals 39, 399-412.

[37] Hawthorne F. C. (1976) Hydrogen positions in scorodite. Acta Crystallogr. B 32, $2891-2892$.

[38] Morin G., Rousse G. and Elkaim E. (2007) Crystal structure of tooeleite, a new iron arsenite hydroxysulfate relevant of acid mine drainage. Amer. Mineral. 92, 193-197.

[39] Ravel B. and Newville M. (2005) ATHENA, ARTEMIS, HEPHAESTUS: data analysis for X-ray absorption spec- troscopy using IFEFFIT. J. Synchrotron Rad. 12, $537-541$.

[40] Delavat F., Lett M.-C., and Lièvremont D. (2012) Novel and unexpected bacterial diversity in an arsenic-rich ecosystem revealed by culture-dependent approaches. Biology Direct 7:28. 
[41] Street G. B. (1970) The structure and thermal properties of synthetic realgar $\left(\mathrm{As}_{4} \mathrm{~S}_{4}\right)$. Journal inorganic nuclear chemistry 32, 3769-3774.

[42] Dill, H. G. (2001) The geology of aluminium phosphates and sulfates of the alunite group minerals: a review. Earth-Science Reviews 53 (1-2), 35-93.

[43] Pe-Piper G., and Dolanski L. M. (2005) Early diagenetic origin of Al phosphatesulfate minerals (woodhouseite and crandallite series) in terrestrial sandstones, Nova Scotia, Canada. American Mineralogist 90 (8-9), 1434-1441.

[44] Muhe M. E., Morin G., Scheer L., Le Pape P., Esteve I., Daus B., Kappler A. (2016) Arsenic(V) incorporation in vivianite during microbial reduction of $\operatorname{arsenic}(\mathrm{V})$-bearing biogenic Fe(III) (oxyhyd)oxides. Environmental Science \& technology, in press.

[45] Xu J., Murayama M., Roco C. M., Veeramani H., Michel F. M., Rimstidt D., Winkler C., Hochella Jr. M. F. (2016b) Highly-Defective nanocrystals of $\mathrm{ZnS}$ formed via dissimilatory bacterial sulfate reduction: a comparative study with their abiogenic analogues. Geochimica et Cosmochimica Acta, in press.

[46] Nancucheo I., Johnson D. B. (2014) Removal of sulfate from extremely acidic mine waters using low pH sulfidogenic bioreactors. Hydrometallurgy 150, 222-226.

[47] Eary, L. E., (1992) The solubility of Amorphous As2S3 from 25 to $90^{\circ} \mathrm{C}$. Geochim. Cosmochim. Acta 56, 2267-2280.

[48] Miot J., Morin G., Skouri-Panet F., Ferrard C., Poitevin A., Aubry E., Ona-Nguema G., Juillot F., Guyot F., Brown G. E. (2009) Speciation of arsenic in euglena gracilis cells exposed to As(V). Environmental Science \& Technology 43 (9), 3315-3321.

[49] Ledbetter R. N., Connon S. A., Neal A. L., Dohnalkova A., and Magnuson T. S. (2007) Biogenic mineral production by a novel arsenic-metabolizing thermophilic bacterium from the Alvord basin, Oregon. Applied and environmental microbiology 73 (18), 5928-5936. 
[50] Rickard D., and Luther G.W. (2007) Chemistry of Iron Sulfides. Chem. Rev. 107, $514-562$.

[51] Wilkin R. T., wallschlager D., and Ford R. G. (2003) Speciation of arsenic in sulfidic waters. Geochemical Transactions 4, 1-7.

[52] Xu L., Wu X., Wang Shaofeng, Yuan Z., Xiao F., Ming Y., and Jia Y. (2016a) Speciation change and redistribution of arsenic in soil under anaerobic microbial activities. Journal of hazardous materials 301, 538-546. 


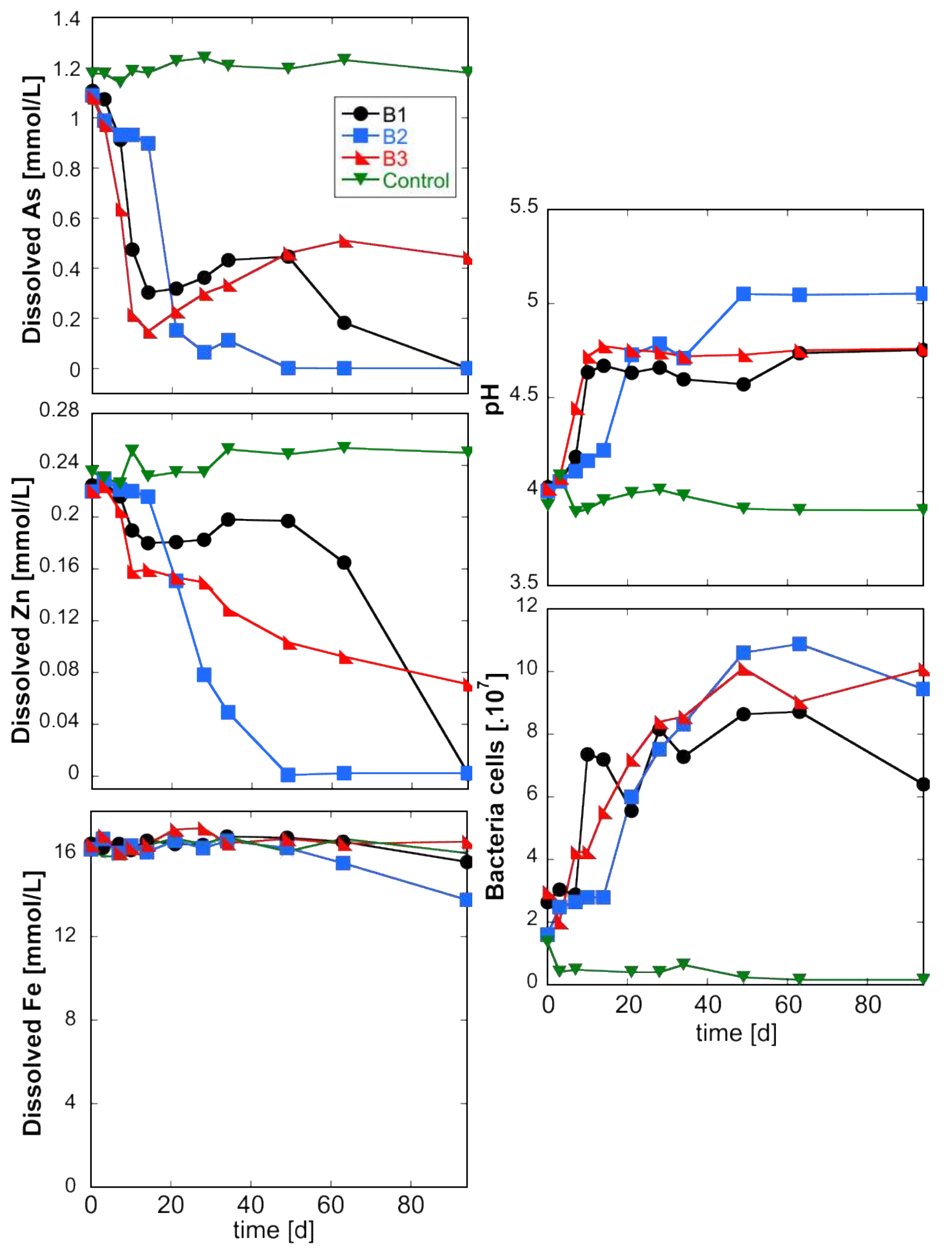

Figure 1. Evolution of $\mathrm{pH}$, number of bacteria cells, dissolved As, dissolved $\mathrm{Zn}$ and dissolved Fe concentrations in solution during the 94 days of experiment. 

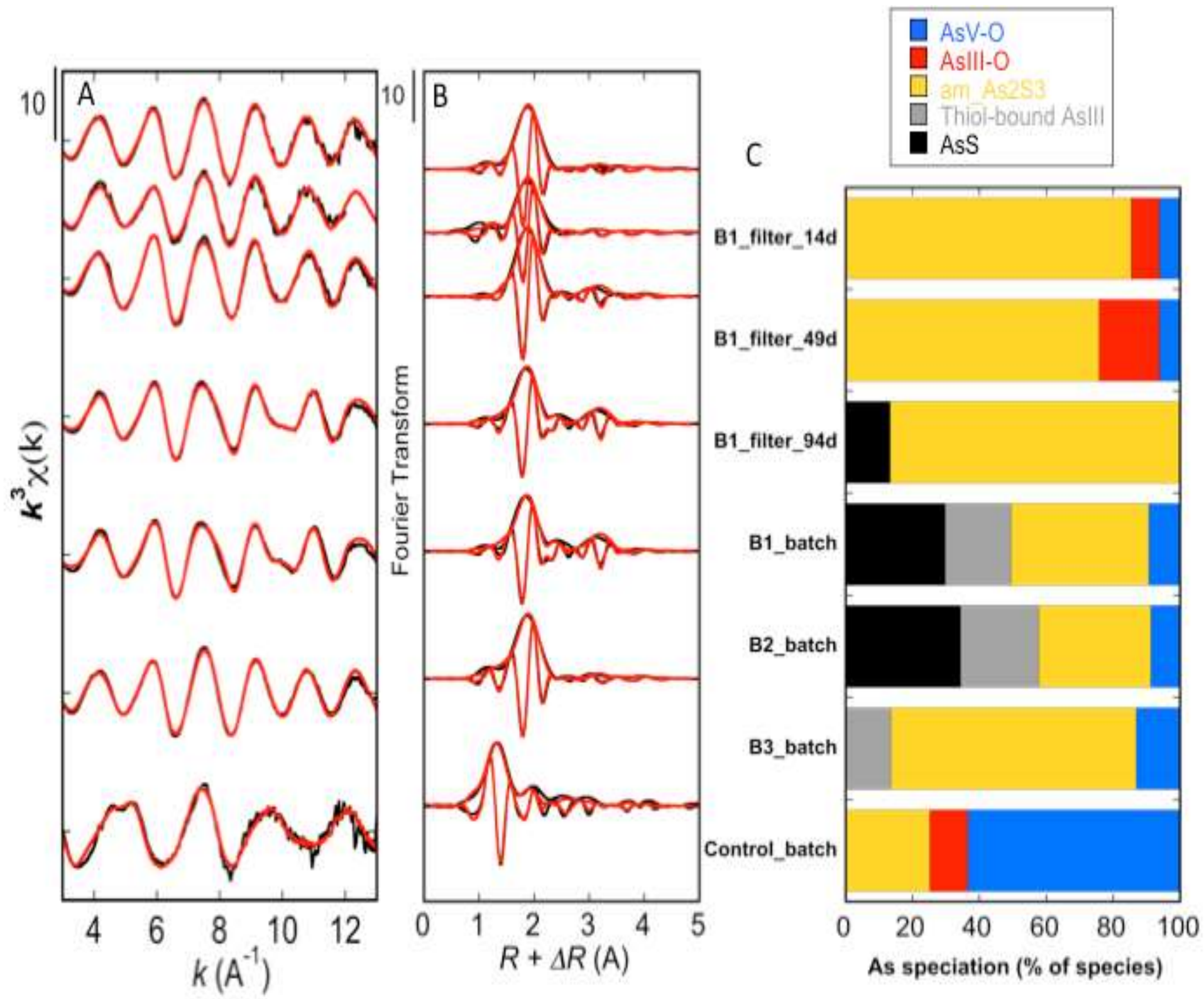

Figure 2. As K-edge X-Ray absorption spectroscopy data and associated LCF analysis of the biofilm samples collected over the course of the B1 experiment and at the end of the B1, B2, B3 and control experiments. A. Experimental $\mathrm{k}^{3}$-weighted EXAFS functions (black lines) and curves simulated by LCF (red lines). B. Fast Fourier transforms of the experimental and LCFreconstructed $\mathrm{k}^{3}$-weighted EXAFS signals. C. Normalized contributions of the different Asbearing species in the biofilm samples. Uncertainties on the contributions as well as original contributions of the different As-bearing species are indicated in Table 1. Analysis of the reference compounds used for reconstructing the experimental EXAFS signals are given in Figure SI-1, Tables SI-4 \& SI-5. 


\section{Aluminium arsenate/phosphate}

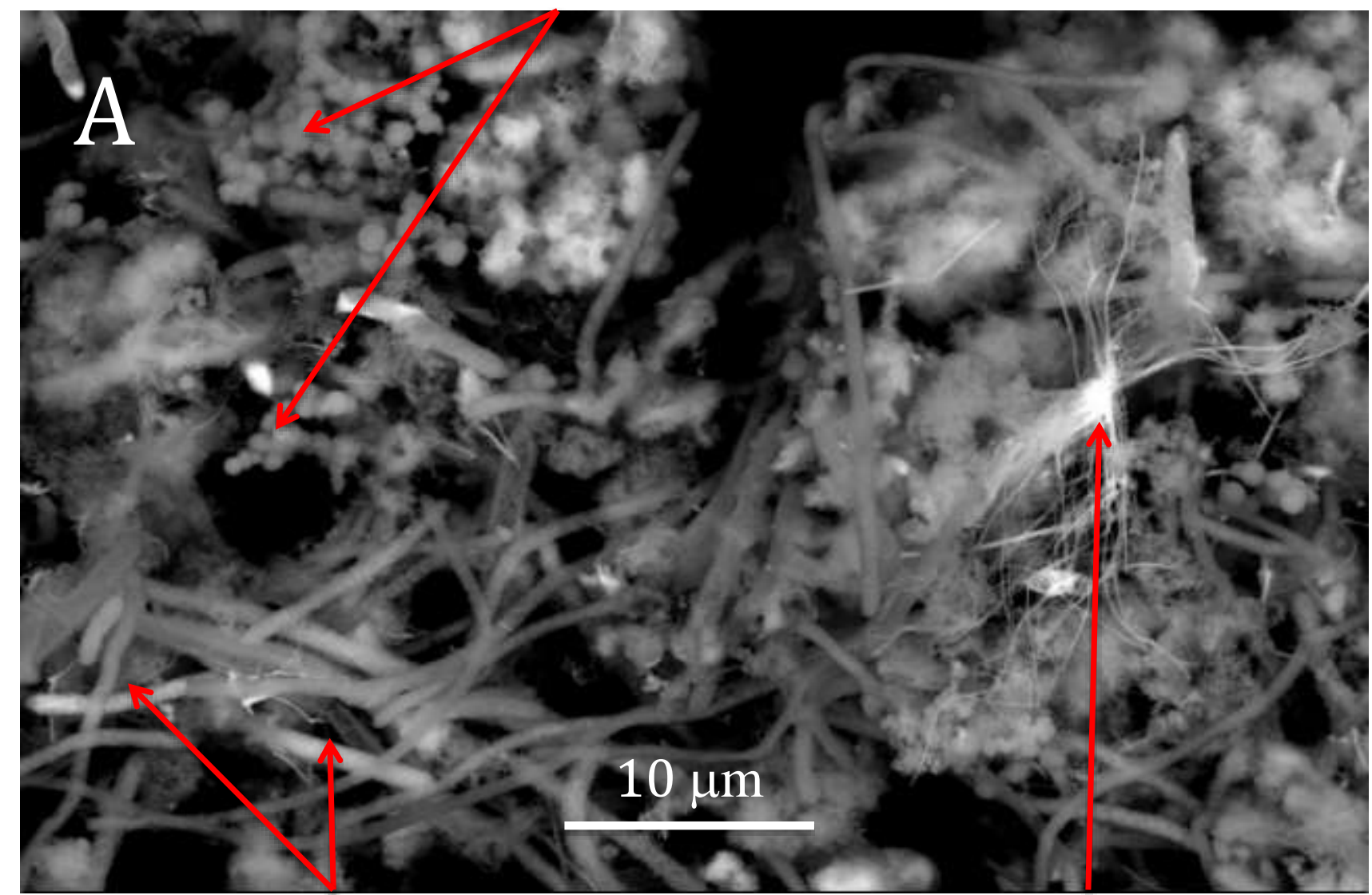

Mineralized cells

AsS nanowires

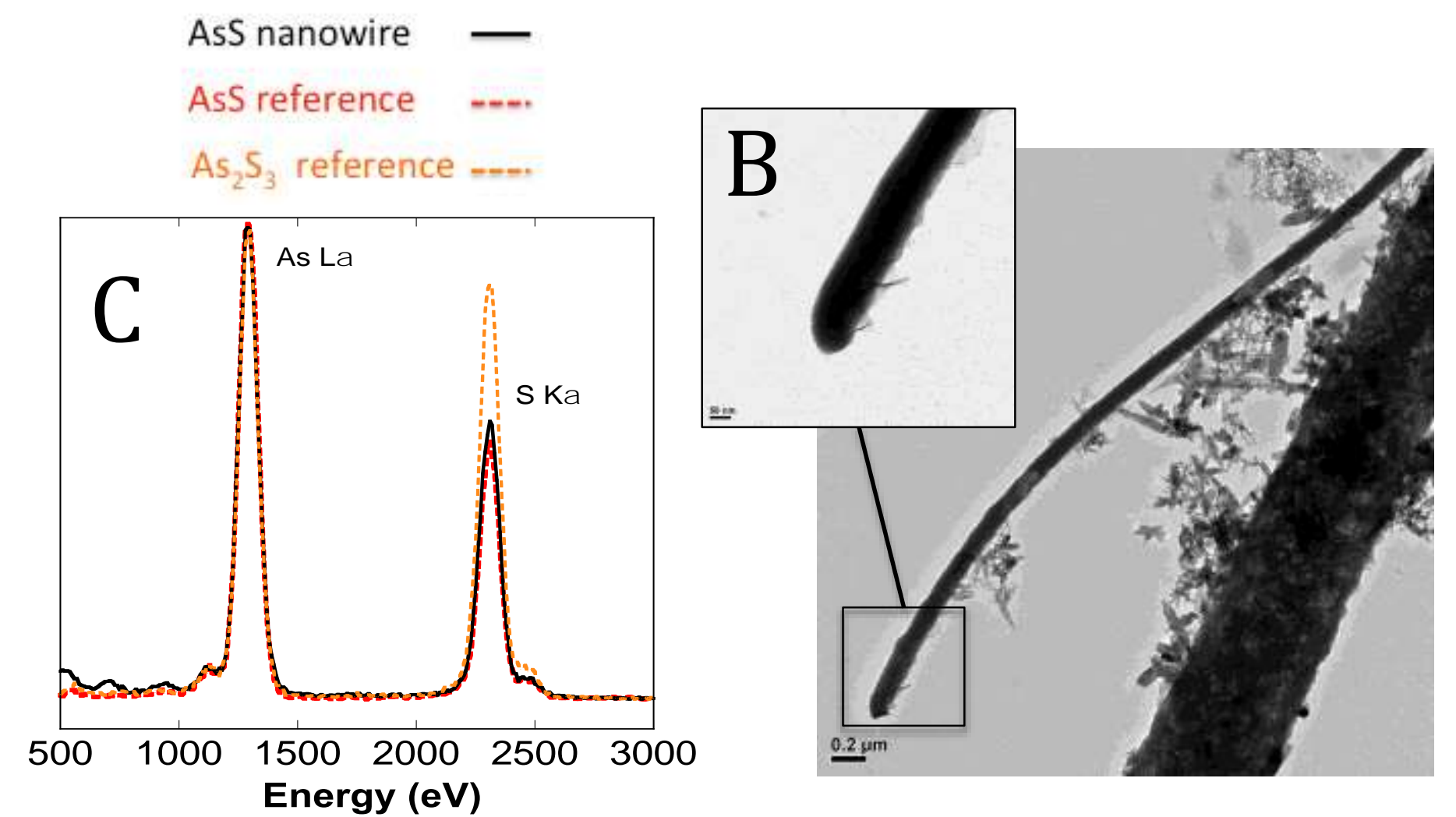


Figure 3. Scanning and transmission electron micrographs and microanalysis from the B2 biofilm. A. General view using backscattered electron imaging. Brillance contrasts allow identifying diverse biofilm components such as As-bearing APS (aluminium phosphatesulfate), As-mineralized microbial cells and realgar (AsS) nanowires. B. TEM observation of a single realgar nanowire close to a microbial cell. Zoom on the realgar nanowire points out the area where the microanalysis was performed. C. Energy dispersive X-Ray spectroscopic diagram of the realgar nanowire presenting the respective intensity of $A s$ L $\alpha$ and $S K \alpha$ emission lines compared to As-sulfide minerals whose stoichiometry is known (Realgar (AsS) and orpiment $\left.\left(\mathrm{As}_{2} \mathrm{~S}_{3}\right)\right)$. 
Table 1. Results of the linear combination fitting (LCF) procedure applied to As K-edge EXAFS data using selected reference compounds (Figure SI-1, Tables SI-4 \& SI-5). LCF were performed using the Athena software. Contributions of the As-bearing species in the biofilm samples are reported as \% without normalizing to $100 \%$. R-factor $\left(\mathrm{R}_{\mathrm{f}}\right)$, chisquare $\left(\mathrm{chi}^{2}\right)$ and reduced chi-square $\left(\mathrm{Red}-\mathrm{chi}^{2}\right)$ are given as classical estimators of the goodness of fit. Uncertainties on the contributions are given in parentheses and refer to 3 sigma obtained with the Athena software.

\begin{tabular}{l|lllll|lll} 
Biofilm samples & $\mathrm{As}^{\mathrm{V}}-\mathrm{O}$ & $\mathrm{As}{ }^{\mathrm{III}}-\mathrm{O}$ & $\mathrm{Am}_{-} \mathrm{As}_{2} \mathrm{~S}_{3}$ & $\mathrm{As}-(\mathrm{glu})_{3}$ & $\mathrm{AsS}$ & $\mathrm{R}_{\mathrm{f}}$ & chi $^{2}$ & Red-chi $^{2}$ \\
\hline B1_filter_14d & $6(2.5)$ & $8(4)$ & $76(3)$ & - & - & 0.0235 & 43.7 & 0.221 \\
B2_filter_14d & $5(3)$ & $16(5)$ & $65(5)$ & - & - & 0.0369 & 49.1 & 0.276 \\
B3_filter_14d & - & - & $75(4)$ & - & $12(4)$ & 0.0209 & 45.7 & 0.230 \\
& & & & & & & & \\
B1_batch & $8(2)$ & - & $34.5(7)$ & $17(7)$ & $25(4)$ & 0.0226 & 31.8 & 0.161 \\
B2_batch & $7(3)$ & - & $28(9)$ & $19(8)$ & $28(5)$ & 0.0315 & 47.8 & 0.243 \\
B3_batch & $12(2)$ & - & $64(7)$ & $12(6)$ & - & 0.0163 & 31.2 & 0.158 \\
Control_batch & $53(6)$ & $9.5(9)$ & $21(8)$ & - & - & 0.1049 & 205 & 1.034 \\
& & & & & & & & \\
\hline
\end{tabular}

